\title{
The Necessity of Teaching Pragmatics in the Iraqi EFL Context: Focus on Secondary Schools
}

\author{
Ahmed Ibrahim Elttayef Al-Abdali, Associate Prof. Dr. Mahendran Maniam
}

Faculty of Languages and Communication, University Pendidikan Sultan Idris (UPSI), Department of English Language and Literature, Malaysia

\begin{abstract}
At present, English plays a key role in the world and it is known as an international language which enables people to connect all around the world and English can be called as a global language because it is helpful in the processes of globalization. As English has played an indispensable role in global communication, it is essential for English language users, both native and non-native, to use clear, comprehensible and educated English that allows smooth communication and avoids misunderstandings in social interactions. Hence, pragmatic competence can facilitate language users to successfully achieve their communicative aims in intercultural communication. Consequently, pragmatic elements have noticeable roles in communication between speakers because such elements can hinder inaccuracies and misunderstandings during communication. This paper discusses pragmatics as a branch of linguistics and its significant role in learning English as a second and a foreign language. In pragmatics, meaning in communication can be classified into two elements; verbal and nonverbal. This classification depends on the contexts, relationship between utterers, and social factors. Teachers should teach pragmatic competence in second language English classes through different activities and tasks.
\end{abstract}

Keywords-pragmatics, pragmatics competence, English language teaching, language competencies.

\section{INTRODUCTION}

Communication is an indispensable part of any community life in which people feel the need to interact with each other for certain reasons. It is through the concept of language that people can communicate with a number of interlocutors in a variety of settings. However, while interacting, people need to follow things beyond words. They need to know how to say something as well as when, where and to whom to say it. Therefore, communication is much more than putting some words in a linear order to form a set of items. Language users are supposed to follow some conventions according to which their conversation will be not only meaningful but also appropriate. This analysis of how to say things in appropriate ways and places is basically called pragmatics. Pragmatics mainly deals with what is beyond the dictionary meanings of statements; in other words, it is about what is actually meant with an utterance based on the norms and conventions of a particular society, or context, in which conversation takes place. Crystal (1997) believes that English becomes a truly global language since then it has kept its privileged position among other world languages towards the end of the 20th century. It is estimated that about 1.5 billion people all over the world speak English.
According to Wardhaugh (1987), "What is remarkable about English and what makes it unique is the extent to which it has spread throughout the world. No other language has ever had the influence in world affairs that English has today." English is viewed as international language by many scholars and researchers, Richards (2001) discussed that English is no longer viewed as the property of the English-speaking world but it is an international commodity sometimes referred to as English an International Language.

\section{THE DEFINITIONS OF PRAGMATICS}

Pragmatics is defined and viewed differently by different scholars and researchers. Morris defined pragmatics as "the study of the relation of signs to interpreters" (1938, p. 6). Yule (1996) defined pragmatics as "the study of meaning". According to Yule, "pragmatics is concerned with four dimensions of meaning: The study of speaker meaning The study of contextual meaning The study of how more gets communicated than is said The study of the expression of relative distance" (p. 3). For Mey (2001), pragmatic is the use of language in communication. Roever (2010), related pragmatics with the 
"interrelationship between language use and the social and interpersonal context of interaction". Thomas (1995) viewed the study of pragmatics as the process of meaning in interaction. Thomas pointed out that "making meaning is a dynamic process, involving the negotiation of meaning between speaker and hearer, the context of utterance (physical, social and linguistic) and the meaning potential of an utterance" (p. 22). For Trosborg (1995) pragmatics analyzes linguistic words in people's communication and to interrupt what people mean in a particular context and how the context influences what is said. It examines how speakers organize what they want to say in accordance with who they are talking to, when, where, and under what circumstances (Yule, 1996). According to Crystal (1997) pragmatics is "the study of language from the point of view of users, especially of the choices they make, the constraints they encounter in using language in social interaction and the effects their use of language has on their participants in the act of communication." Thus, pragmatics is "communicative action in its sociocultural context" (Rose \& Kasper, 2001).

\section{THE CLASSIFICATIONS OF LANGUAGE COMPETENCIES}

Language competencies can be classified into subcompetencies in the following:

1) Grammatical competence: it includes individual's knowledge of vocabulary, morphology, syntax, and phonology (Bachman, 1990).

2) Communicative competence: Canale \& Swain (1980) propose that communicative competence includes sociolinguistic competence. Niezgoda \& Rover (2001) summarize the sub-competencies under this model as follows:

a) Grammatical competence: it includes morphology, syntax, semantics, and phonology;

b) Sociolinguistic competence: The knowledge of using language in context;

c) Discourse competence: The coherence and cohesion knowledge in spoken or written communication;

d) Strategic competence: The knowledge of how to use communication strategies to handle breakdowns in communication and make communication effective.

Bachman's (1990) mode 1 of communicative competence provides knowledge's required to use language appropriately. In addition to the knowledge of grammatical rules, communicative competence consists of the knowledge of how language is utilized to achieve particular communicative goals. He categorizes language competence into organizational competence and pragmatic competence. Organizational competence relates to a speakers' control of the formal aspects of language and is further subdivided into grammatical competence (vocabulary, syntax, morphology, phonology), and textual competence (cohesion/coherence, rhetorical organization). As noted by Niezgoda \& Rover (2011), Pragmatic competence is classified into sociolinguistic and illocutionary competence. Figure 1 shows the language competence.

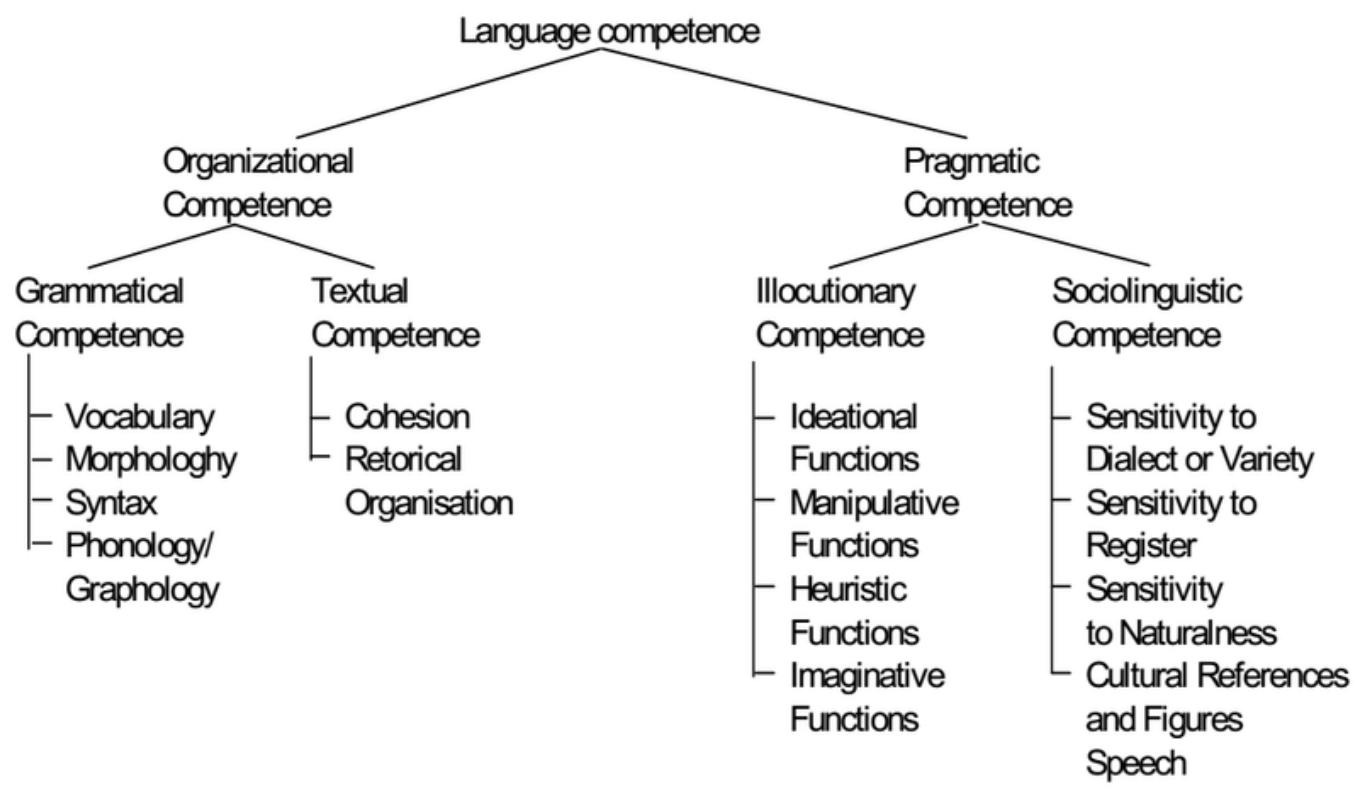

Fig.1: Bachman (1990) Language Competence 


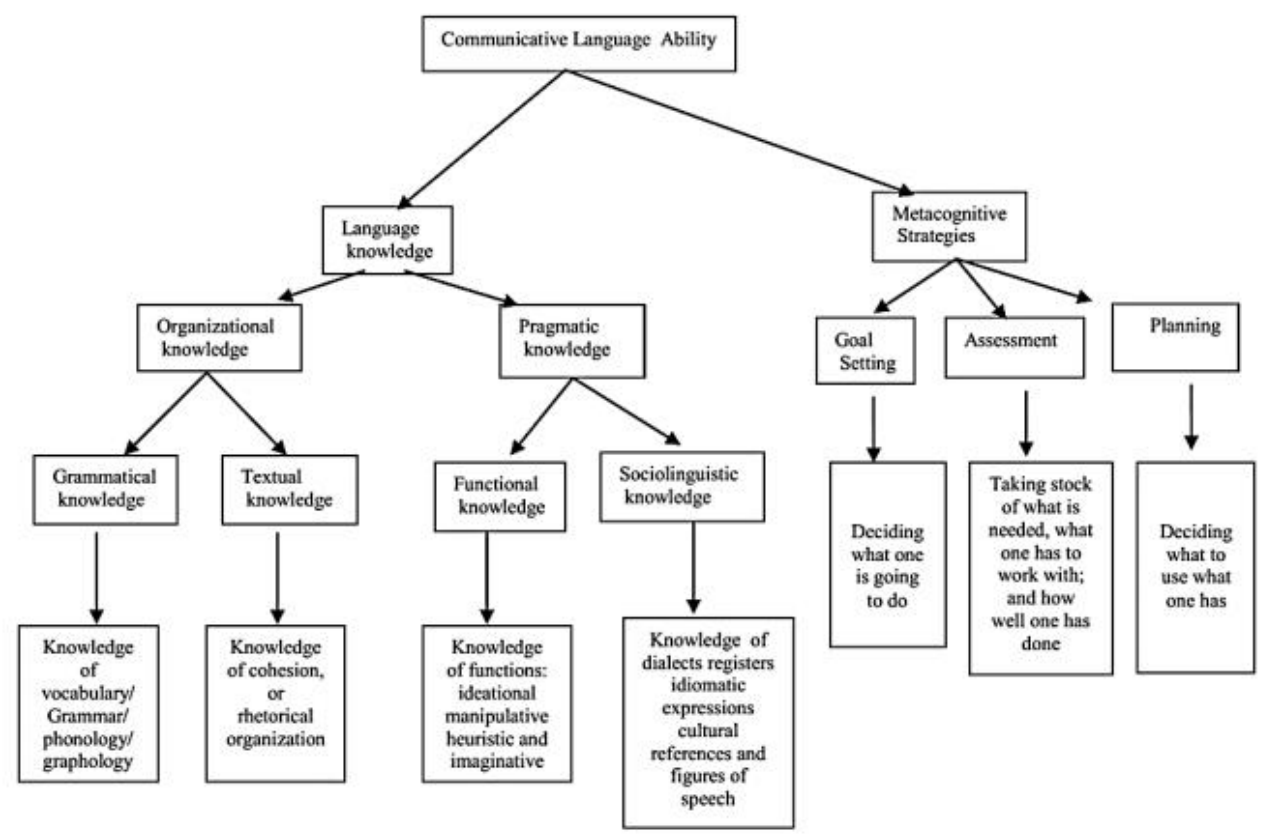

Fig.2: Bachman and Palmer's Framework of Communicative Language Ability

\section{Pragmatic competence}

According to Taguchi (2003), pragmatic knowledge "deals with language use in relation to language users and language use settings. Thomas (1995), Pragmatic competence means the ability to use language in socially appropriate ways and to interpret both implicit and explicit meaning according to context. Since the mid-1970s, the general purpose of language teaching and assessment concentrates on developing learners' communicative competence, knowledge of the pragmatics and linguistics aspects of language use to enable students to become proficient in the target language." Leech (1983). Bachman (1990) supports this approach and describes language ability broadly as "the ability to use language communicatively." He proposes two models in his model which includes two elements: language knowledge and strategic competence. Language knowledge consists of "organizational knowledge" and "pragmatic knowledge." The pragmatic knowledge hereafters to considers the appropriateness of a particular communicative goal (what he calls "functional knowledge") and the appropriateness of the language use setting ("sociolinguistic knowledge").According to Bachman and Palmer (1996), pragmatic knowledge involves the relationship between utterances, language users, and settings support the views of well-known researchers in the field that came before them. Crystal (1985) defines pragmatics as "the study of language from the point of view of users, especially of the choices they make, the constraints they encounter in using social interaction and the effects their use of language has on other participants in the act of communication." Rose and Kasper (2001) develop the concept of communicative ability and summarize the study of pragmatics as "the study of communicative action in its sociocultural context." Communicative action happen not only when one engages in different types of discourse encountered in social situations (which vary in length and complexity depending on the degree of familiarity between interlocutors, differences in social status, and degree of imposition), but also when speech acts (such as requests, refusals, apologies, compliments, and suggestions) are employed.

\section{PRAGMATICS TEACH ABILITY}

According to several ILP studies on how to teach pragmatics which teachers are interested in. on the basis of both empirical and theoretical studies, Awareness-raising is one of an effective approach to the teaching of pragmatics. The purpose of this approach is to develop learners' pragmatic awareness through classroom application of available descriptive frameworks and research results. It does not attempt to teach specific means of, say, performing a given speech act, but rather attempts to sensitize learners to context-based variation in language use and the variables that help determine that variation (Rose,1994).Drawing from research that focuses on the significance of noticing in language acquisition and L1 
pragmatics development, Schmidt (1993) believes awareness of pragmatic input is considerable for the acquisition of pragmatic competence and in the development of L2 pragmatics. "Consciously noticing to the relevant features of input and attempting to analyze their significance in terms of deeper generalization are both highly facilitative." Hence, tasks that focus the learner's attention on pragmatic forms, functions, and co-occurring features of social context are helpful in developing adult language learners' ILP. Empirical studies in ILP and contrastive pragmatics also indicate that awareness-raising facilitates students in using the pragmatic knowledge they already possess. Kasper (1997) discovers that L1 and L2 speakers have access to identical lists of semantic formulae and other pragmatic resources, but language learners underuse universal or L1 pragmatic knowledge. Therefore, awareness -raising activities are helpful in making language learners aware of their existing pragmatic competence and encouraging them to utilize the pragmatic resources they already possess. One of the main shortcomings of teaching pragmatics for teachers is that it is so extremely context dependent. No "magic line" will be appropriate for all contexts, and it is equally unrealistic to attempt to cover all contexts that students could possibly encounter. By being taught to be aware of pragmatics in various contexts, learners can develop the ability to understand pragmatic patterns in new and previous contexts

\section{THE ROLE OF PRAGMATIC COMPETENCE IN THE PROCESS OF TEACHING AND LEARNING A FOREIGN/SECOND LANGUAGE}

The four language skills in language learning such as reading writing, listening and speaking do not occur in isolation in communicative texts or activities. Through forming a good pragmatic competence for the language learner, the following should be considered. The aims of a language course should be designed to meet the needs of the language learner to help them improve their communicative competence. Since the primary goal of learning a second language is to provide fluency and accuracy in written and spoken modes of communication, first, the language teacher and the learner should notice to design communicative activities which help to develop the communicative competence. Pragmatic competence should be considered as an inseparable component of language competence. Therefore, pragmatic features of the target language should be incorporated in language instruction as well as linguistic features. In order to equip learners with the essential pragmatic knowledge, it can be suggested that, first of all, the importance of pragmatic competence should be internalized. Then the perspectives should be reshaped with the purpose of providing learners with the best opportunities to expose to the pragmatic features and practice them in a variety of contexts. In addition, language teachers should possess a good command of the target language including a satisfactory level of pragmatic knowledge so that they can convey what they know to their learners. In order to teach their learners these pragmatic aspects, teachers should also have the necessary teaching skills enabling them to adopt different teaching strategies during their instruction.

\section{CONCLUSION}

The notion of pragmatics should be noticed as a significant branch of linguistics in English teaching especially pragmatic competence along with other four language skills. Through various teaching and learning activities, the development pragmatic competence can be demonstrated to L2 learners and teachers should accept that pragmatic competence is one of the primitive teaching goals. By applying pragmatic competence in English teaching in class, learners can realize various levels of grammars and functions well in an accurate, fluent, and coherent way. To sum up, pragmatic competence is one of the building blocks of language instruction. If the aim of language education is to teach learners how a language should be appropriately and effectively used in different interactional settings, it is important to raise learners' pragmatic awareness as well as furnishing them with some beneficial strategies they can utilize to sustain successful communication in diverse settings with different interlocutors. Therefore, pragmatic competence should be an integral part of language curriculum. In order to accomplish this, however, there is still some need for further research aiming to raise much more awareness considering the significance of pragmatic competence and to come up with better and more productive suggestions and solutions.

\section{REFERENCES}

[1] Bachman, L. (1990). Fundamental consideration in language testing. New York: Oxford University Press.

[2] Bachman, L., \& Palmer, A. (1996). Language testing in practice: Designing and developing useful language tests. Oxford:Oxford University Press.

[3] Canale, M., \& Swain, M. (1980). Theoretical aspects of communicative approaches to second language teaching andtesting. Applied Linguistics, 1, 1-47.

[4] Crystal, D. (1985). A dictionary of linguistics and phonetics (2nd Ed.). Oxford: Blackwell. 
[5] Crystal, D. (1997). English as a global language. Cambridge: Cambridge University Press.

[6] Erton, I. (2007). Applied Pragmatics and Competence Relations in Language Learning and Teaching, Journal of Language and Linguistic Studies, Vol.3, No.1, April 2007

[7] Held, D., McGrew, A., Goldblatt, D., \&Perraton, J. (1999). Global transformations: Politics, economics and culture. Cambridge: Polity Press.

[8] Kachru, B.B., \& Nelson, C.L. (2001). World English's. In A. Burns, \& C. Coffin (Eds.), Analyzing English in a global context (pp. 9-25). London and New York: Routledge.

[9] Kasper, G. (1997). Can pragmatic competence be taught? NFLRC NetWork (6) Honolulu: University of Hawaii, Second Language Teaching and Curriculum Center. Retrieved from http://nflrc.hawaii.edu/networks/NW06/default.html.

[10] Leech, G. (1983). Principles of pragmatics. London: Longman.

[11] Levinson, S. (1983). Pragmatics. Cambridge: Cambridge University Press.

[12] Mey, L. J. (1993). Pragmatics: An Introduction. Oxford: Blackwell Publishers.

[13] Morris, C. H. (1938). Foundation of the theory of signs. In O. Neurath (Ed.), International Encyclopedia of Unified Science (vol. 1) Chicago: University of Chicago Press.

[14] Niezgoda, K., \& Röver, C. (2001). Pragmatic and grammatical awareness: A function of the learning environment. InK. R. Rose \& K. Kasper (Eds.), Pragmatics in Language Teaching (pp.1-12). Cambridge: Cambridge University Press.

[15] Richards, J.C. (2001). Communicative Language Teaching Today. New York: Cambridge University Press.

[16] Roever, C. (2010). Researching pragmatics. In B. Paltridege \& A. Phakiti (Eds.), Continuum Comparison to Research Methods in Applied Linguistics (pp. 240-255). London, New York: Continuum International Publishing Group.

[17] Rose, K. R. (1994). Pragmatic Consciousness s-Raising in an EFL Context.

[18] Rose, K. R., \& Kasper, K. (Eds.). (2001). Pragmatics in language teaching. Cambridge: Cambridge University Press.

[19] Schmidt, R. (1993). Consciousness, learning and interlanguage pragmatics. In G. Kasper \& S. Blum-Kulka (Eds.), Inter language Pragmatics (pp. 21-42). New York: Oxford University Press.

[20] Stern, H. H. (1983). Fundamental Concepts of Language Teaching. Oxford: Oxford UP

[21] Taguchi, N. (2003). Pragmatic performance in comprehension and production of English as a second language. Dissertation Abstracts International, 65(01), 134A. (UMI No. 3118493)

[22] Thomas, J. (1995). Meaning in interaction: An introduction to pragmatics. London: Longman.

[23] Trosborg, A. (1995). Interlanguage pragmatics: Requests, complaints and apologies. Berlin, New York: Mouton de Gruyter.

[24] Wardhaugh, R. (1987). Languages in competition. Dominance, diversity, decline. Oxford: Ba sil Blackwell.
[25] Yule, G. (1996). Pragmatics. Oxford: Oxford University Press. 